\title{
The Zipsers' Ethnic Identity in Vişeu de Sus/Oberwischau, Romania, in the Context of INTER-Ethnic Relationships
}

\author{
Ioana SCRIDON, Augsburg, and Oana-Ramona ILOvAn, Cluj-Napoca*
}

with 2 figures in the text

\section{CONTENTS}

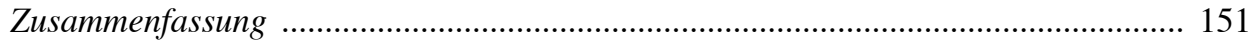

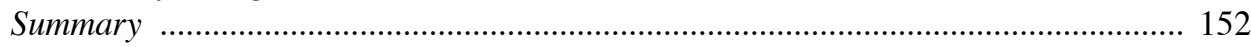

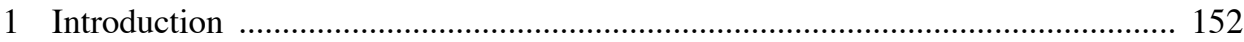

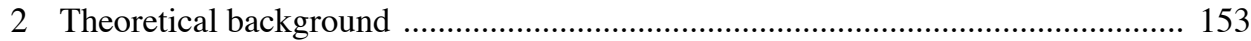

3 Material and method ................................................................................... 155

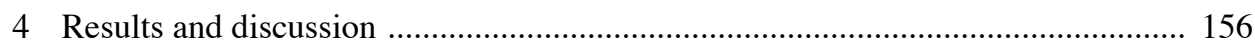

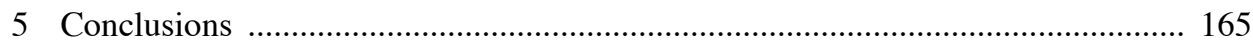

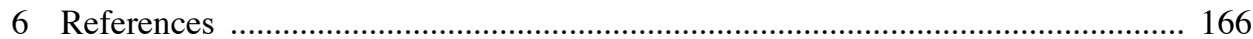

\section{Zusammenfassung}

Die ethnische Identität der Zipser in Vişeu de Sus/Oberwischau, Rumänien, im Kontext der interethnischen Beziehungen

Diese Arbeit untersucht die Gemeinschaft der Zipser in Vişeu de Sus/Oberwischau. Diese ethnische Gruppe zählt zu den relevanten kleineren deutschsprachigen ethnischen Minderheiten im Osten und Südosten Europas. Ihr räumliches Zusammenleben mit anderen ethnischen Gruppen führte zu besonderen Anpassungen und bedingte die Entstehung einer neuen ethnischen Grundlage, die sich durch die eigenartige Kultur äußert (Sprache, Traditionen, Religion). Zweck der Forschung war es, aufzuzeigen, dass die Multikul-

\footnotetext{
* Ioana Scridon, PhD, External scientific collaborator of the Bukowina-Institut Augsburg (Institute of the Augsburg University), Alter Postweg 97A, D-86159 Augsburg, Germany; email: scridon.ioana@yahoo.com; Oana-Ramona Ilovan, PhD, Lecturer, Babeş-Bolyai University Cluj-Napoca, Faculty of Geography, ClujNapoca, Str. Clinicilor 5-7, RO-400006, Romania; email: ilovanoana@yahoo.com
} 
turalität in manchen Fällen, wie hier bei den Zipsern in Vişeu de Sus, für die Wahrung der Identität und der kulturellen Traditionen förderlich sein kann. Die Grundlage dieser Fallstudie bilden die Selbstbiographien der Gewährspersonen und die ethnographische Untersuchung als Ergebnis der Gespräche, Fragebögen und Beobachtungen wie auch die statistischen Daten der Volkszählungen, weiterhin die Informationen aus früheren Studien und unsere eigenen theoretischen Schlussfolgerungen und Überlegungen. Die Ergebnisse belegen, dass die Besonderheiten dieser ethnischen Gruppe und vor allem ihr Fortbestand über Jahrhunderte eben dieser multikulturellen Grundlage zu verdanken sind, die den Respekt den Anderen gegenüber ermöglichte wie auch Kommunikation und gegenseitige Unterstützung hervorbrachte, eben das „Miteinander Leben“. Anhand der Untersuchung kamen wir zur Schlussfolgerung, dass dieses Konstrukt der ethnischen Identität in einer Wechselwirkung mit dem Anderen entstand und auch das Ergebnis von sozialem Wandel und Spaltungen war, die von politischen Ereignissen verursacht wurden.

Schlagwörter: Zipser, Identität, interethnische Beziehungen, qualitative Forschungsmethoden, , die Anderen', Multikulturalität

\section{Summary}

In this paper, we report on the Zipsers' community in Vişeu de Sus/Oberwischau, Romania. This ethnic group is one of the most relevant examples out of the German-speaking ethnic groups in Eastern and Southeastern Europe that living together and sharing space with other ethnic groups lead to characteristic adaptations and influence the appearance of another ethnic substratum visible through its own culture (language, tradition, religion, etc.). Our aim was to show that multiculturalism may in some cases, such as the Zipsers' in Viseu de Sus/Oberwischau, support identity and traditional culture preservation. The material of our research rested on respondents' autobiographies and on ethnographic inquiry as resulted from interviews, questionnaires and observation, on statistical data from censuses, on information from earlier studies and on our theoretical reflection. Results showed that the specificity of this ethnic group and especially of its perpetuation was exactly the multicultural substratum that enabled respecting the Other, communication and help-based ethnic relationships, that is "living together". We concluded that the Zipsers' construction of ethnic identity was done depending on the Other, as a result of social transformation and of fragmenting triggered by political events.

Keywords: Zipsers, identity, interethnic relationships, qualitative research methods, 'the Other', multiculturalism

\section{Introduction}

Zipsers' spreading is a relatively small one, with representatives in Romania (Maramureş, Bucovina and Banat), in Ukraine (Transcarpathia [Zakarpattja]) and in Germany (nearby big industrial cities such as Ingolstadt, Nuremberg [Nürnberg], Oldenburg, Singen, etc., where there were the most important camps for receiving the Germans from 
Eastern Europe, as well as industrial cities). Their communities are characterised by negative demographic increase and high rates of ageing. Their living environment is mainly rural, except in Germany. The Zipsers speak a German idiom called the Zipsers' [das Zipserische]. Within their ethnic community they use often other languages such as Hungarian, Romanian and Ukrainian.

The Zipsers' origin is similar to that of the Transylvanian Saxons [Siebenbürger Sachsen]. During the population waves of the $12^{\text {th }}$ and $13^{\text {th }}$ centuries, a part of the Saxons headed to Transylvania [Transilvania] in modern Romania and thus received the name of Transylvanian Saxons, and another part headed to the Zips Region [Spiš] in modern Slovakia and received the name of Zipser Saxons [Zipser Sachsen]. The Saxons from Zips adapted to the living and work circumstances, some of them being miners or working in forestry. Some of the Germans near the Tatra Mountains [Tatry], because of famine, overcrowding, lack of jobs and religious insecurity entered the large colonisation process started by Empress Maria Theresia of Austria. Thus, at the end of the $18^{\text {th }}$ century and at the beginning of the $19^{\text {th }}$ century, she resettled the Zipsers directly or she called for them from the regions in the eastern periphery of the Empire, either because they were already skilful in mining and forestry or because she needed them to defend the borders. Within the present borders of Romania, the Zipsers were settled in Banat, in Bucovina and in Maramureș (SCRIDON 2012c, p. 9).

In Romania, the most representative community of Zipsers is in Vişeu de Sus/Oberwischau ${ }^{1)}$, where group identity has been expressed, for several centuries, by their grouping in a quarter bearing their name and first planned to be apart from Romanians' households and having a self-administration function (ILK 2011; SCRIDON 2012b; SCHMITZBERGER 2014).

This study of Cultural Geography has the aim to show that multiculturalism may in some cases, such as the Zipsers' in Vişeu de Sus/Oberwischau, support identity and traditional culture preservation, thus in fact postponing the unavoidable assimilation and ethnic levelling process. Their ethnic group in Vişeu de Sus/Oberwischau is one of the most relevant examples out of the German-speaking ethnic groups in Eastern and Southeastern Europe and implicitly in Romania (where other German-speaking ethnic groups are the Landlers, the Swabians of Satu Mare, the Dobrudja Germans, the German Bohemians, etc.). Living together and sharing space with other ethnic groups lead to characteristic adaptations and influence the appearance of another ethnic substratum visible through its own culture (language, tradition, religion, etc.).

\section{Theoretical background}

As confrontation between cultures could result in co-operation or in more or less violent contact (FERRÉOL 2005, p. 183), there were two important key concepts that we considered while paying attention to researching the Zipsers: culture and identity.

\footnotetext{
1) Since 2001, the place is officially bilingual. This is reflected here by presenting the place name consequently in Romanian as well as in German.
} 
There are several ways, in which cultures and their relations to each other are understood. The first one is that of regarding 'other' cultures as unchanging, traditional, primitive, exotic (different and dangerous), with change to be caused only by outside forces. This is summarised under the term Orientalism, which Edward SAID introduced in 1978 in order to characterise the period of colonialism and imperial rule (Sмітн 2012, pp. 158-159). The second way is that of regarding cultures as dynamic and interconnected, where differences between cultures are erased by globalisation. J. FERRÉOL (2005, p. 183) points out that this idea of mutual cultural enriching is new and caused by two favourable conditions: the interdependence of economies and emigration fluxes. So cultures are not strange and unchanging, but "homogenous" or similar (SмITH 2012, p. 159). Nevertheless, a third way of regarding culture developed while taking diversity into account when we try to understand "how places and cultures are connected to national and global processes in uneven and unequal ways" (MASSEY \& JESS 1995 apud SMITH 2012, p. 159). Finally, the fourth way is that of hybrid and synchretic cultures, that of diaspora or of transnational communities (e.g., in music, fashion, food, the media, etc.) (SмIтH 2012, p. 159).

In this study we observe the third perspective upon culture and F. SMITH's (2012, p. 160) definition of culture as being dynamic and thus complex: "Rather than culture being slow-to-change, fixed set of beliefs, values and behaviours, with permanent connection to places", Stuart HaLl (1995, p. 187), argues culture is "a meeting point where different influences, traditions and forces intersect", formed by the "juxtaposition and co-presence of different cultural forces and discourses and their effects" and consisting of "changing cultural practices and meanings". This suggests our "own cultures are as caught up in change as other cultures, and the connections between cultures and places can be highly dynamic".

In addition, the questions referring to culture relate to its limits, of the 'space' of this notion: Is culture a prison (RAZA 2013) or only a delimitation imposed by each and every individual? Moreover, is it possible that two cultures share the same territory, but the cultural points where they intersect are small? May one say that cultural stereotypes form within culture? Culture is given, transmitted; it is delimited by language, customs, religion, traditional costume, etc. The effect of culture is from the macro-scale to the micro-scale, it starts from a group and it reflects on the individual and later on it is an image of the total. Thus space becomes not only the 'arena' where ethnic groups live with one another, but even more, space becomes the tool of characteristic identity changes (SLETTO 2002; Gebhardt, Reuber \& Wolkersdorfer 2004; Mills 2006; Crouch 2010).

In this context, the systems of values that are deeply rooted in the history of communities and their manifestation through practices are the identity marks at the basis of culture. At the same time, culture is like a living creature; it becomes stronger and undergoes a renewal process as it offers the possibility for interpretation and for a complementary relationship between tradition and innovation (FERRÉOL \& JuCQUOIS 2005, p. 333, 338; FERRÉOL 2005, p. 183). Taking into account such meanings, sociologists and geographers as well study "the more or less formalised ways of thinking, of feeling and of doing, that being learnt and shared by a number of people create the conditions, in a both objective and symbolic way, to the creation with these people of a particular and distinct community." (ROCHER 1970, p. 111) 
Therefore, taking into account this definition of culture, it means that also identity is, according to a constructivist approach, "an undergoing process and not a fix fact of life" (FERRÉOL \& JuCQUOIS 2005, p. 328). Moreover, identity is dialogical as it may only result through a dialogue with the Other. Similarly, M. Rose considers that "identity is conceived not as something we have but something we are given. Identity is a primordial response to various others, some of which are material and sensible and others wholly infinite and eternally beyond our perceptible horizons." (Rose 2010, p. 507) In addition, individuals are subject to a plurality of simultaneous and/or successive affiliations resulting in their feelings of belonging and in as many identities, because the construction of identity is a matter of perceptions and of categorising (FERRÉOL \& JuCQUOIS 2005, p. 330). In this way appeared the concept of narrative identity which was very useful during our research because each individual's identity is his history and we can access it only due to and through a narration (RICEUR 1990, p. 175).

To sum up, geographers approached their field of study and culture itself in diverse ways, according to various philosophical trends or traditions (B̈̈тZING 2011). Thus, the context of our approach is that of the studies on identity and alterity, on ethnic solidarities and conflicts especially in peasant communities and of that of symbolic geographies (ILOVAN 2009; MEHEDINȚi 2013; Mitu 2013; SOPORAn 2014). There are similar studies drawing on a geography of intimacy (BRYDEN 2004).

\section{Material and method}

The general research context and topic were that of a long-term project, a $\mathrm{PhD}$ thesis ("The Ethnic Group of Romanian Zipsers. Historical Study on Representation Changes of the Identity Space in Vişeu de Sus, Maramureş") realised by Ioana SCRIDON between 2009 and 2012. During this study, the Zipsers' group was researched from multiple perspectives (geographical, historical and cultural) during its evolution, while visiting Zipsers' ethnic groups in Romania, Ukraine and in Germany.

In this paper we report on the Zipsers' community in Vişeu de Sus/Oberwischau, Romania, which is rather old from a demographical perspective. We were there for about 50 days. During that period, we realised interviews. In addition, we did participatory observation, as we took part at religious holidays and at important events in the life of the Zipsers' community.

Interviews best show the inter-ethnic relationships. As a matter of fact, any free and spontaneous discussion may bring forward the ways people relate to each other. Therefore, our research in the field was represented by realising interviews on a certain theme or including a diversity of themes as well as by administering questionnaires to persons of different ages, occupations and with different social backgrounds. These were supplemented with observation, and we realised an analysis of interview transcripts and observation records.

The questionnaires and interviews focused on respondents' biographies, ethnic affiliation, remembering of the past through stories, on culture received by means of their ancestors' stories and memories, on the participatory handing down of culture to younger 
generations, on the specificity of the Zipsers in Vişeu de Sus/Oberwischau, on inter-ethnic relationships and on the main historical events affecting community life and the personal level.

The respondents were mainly Zipsers as the main element we focused on was people's belonging to the Zipsers' ethnic group, speaking a German dialect, as well as on their observing in a preserved or adapted form their characteristic tradition and customs. In addition, we focused also on their bonding and bridging capital, on their place-based belonging, possible to develop a Zipsers' identity and on the importance of the celebration of attributes and values associated with the Zipsers.

The material rests on respondents' autobiography and on ethnographic inquiry as resulted from interviews, questionnaires and observation, on statistical data from censuses, on information from earlier studies and on our theoretical reflection.

\section{Results and discussion}

In order to achieve the aim of this study, we discussed the historical and economic context of Zipsers' settling in Vişeu de Sus/Oberwischau, their colonisation and other ethnic groups' arrival in Vişeu de Sus/Oberwischau, the demographical features of this settlement especially starting with the $20^{\text {th }}$ century, the relationships between the Zipsers and the Other and their culture in the researched community.

\subsection{Historical and economic context}

Beginning with the $18^{\text {th }}$ century, a large part of the Maramures County was under Count Wolfgang Rudnyansky's rule and administration as he bought from the Hungarian authorities the permission to exploit the natural resources in the upper Tisza [Tisa] Valley, with both the forests and the mines in Ocna Şugatag, Coștiui and in Slatina. In this context, this county (a medieval administrative organisation form) underwent an economic reform process in order to realise an as efficient as possible salt mining. To reduce the salt transport costs, they set up the Tisza Valley and the neighbouring ones for log driving and they used the wood exploited from the forests of Maramureș to build rafts on which salt was loaded. During this period, they also started the intensive and organised exploitation of the forests in the Vaser Valley (SCRIDON 2012a).

This was the general context for bringing Austrian and Zipser settlers according to an organised and co-ordinated setting in the southern part of the Maramureş Region.

\subsection{Diverse ethnic groups' arrival in Vişeu de Sus/Oberwischau}

Colonisation begins in 1775 , by bringing Austrian specialists (settlers) from Salzkammergut. They founded settlements such as Deutsch-Mokra [Komsomol's'k], Brustura, and Dubove (all in modern Ukrainian Transcarpathia), and later, in 1778, they were the first that began a secondary organised and continuous salt mining activity in Vişeu de Sus/ Oberwischau. 
The Zipser settlers came to Vişeu de Sus/Oberwischau starting with 1796. The name of these ethnics came from the Zips Region, in Slovakia, nearby the Tatra Mountains. From there, the first organised groups of forestry workers migrated to the eastern part of the Carpathians beginning with the late $18^{\text {th }}$ century. The majority of those, who immigrated to Vişeu de Sus/Oberwischau coming from the Zips Region, at that time called Upper Hungary, were from Käsmark [Kežmarok], Deutschproben [Nitrianske Pravno] and Leutschau [Levoča], and their number increased gradually so that there appeared the issue of organising their coming and building a quarter for them nearby Romanian settlements. Thus, in 1809, the T,ipserai Quarter (in German: Zipser Reihe) was built. The same year, the Austrian architect Ernst Plaud realised the plans of the quarter, and according to these plans authorities distributed the Zipsers (ILK 2011; SCRIDON 2012b; SCHMitZBERGER 2014).

The other ethnic groups from the community in Vişeu de Sus/Oberwischau came during the Zipsers' arrival or later, when the demand for population increased.

The Armenians came between 1778 and 1780, from Gherla/Szamosújvár in northern Transylvania, being craftsmen and mentioned in Historia Domus, a church document registering the significant events of a community, and they built the first houses for selling diverse products (BERNER 2006).

The Ruthenians (Ukrainians) were present starting with 1780. They were registered in Historia Domus, where there was mentioned that their presence is not old. They developed a rich cultural life after 1848 (SCRIDON 2012a).

The Hungarians represented a minority ethnic group in this settlement. Their number and the fact that Jews and Germans declared they were Hungarian, as a result of the forced ethnic assimilation process to this group (called magyarisation), determined the appearance of an oscillating percentage of Hungarians.

The Jews came massively from Galicia and Bucovina between 1840 and 1849 (SCHNEEBERGER \& LANGE 1998, p. 115). Still, their presence in Maramureş was much older, as there are documents about them from the $18^{\text {th }}$ century, especially mentioning they were present in urban centres, such as Sighetu Marmaţiei (DăNCuş \& DĂNCuş 1999, p. 496).

\subsection{Demographical features of Vişeu de Sus/Oberwischau}

During the first years of mentioning in documents the Zipsers in the Vaser Valley and in Vişeu de Sus/Oberwischau (beginning with 1796), the population of Vișeu de Sus/ Oberwischau did not have a significant increase rate, especially the autochthonous one. The natives were the most numerous, their majority being represented by Romanians, organised around the first church in this settlement, which they call nowadays the Old Church [Biserica Bătrână]. The administration belonged to the priest, who was surrounded by several local noblemen, while the rest of the population built their houses on the hills and along the valleys nearby the church.

The ethnic diversity of this settlement in the $19^{\text {th }}$ and $20^{\text {th }}$ centuries was high due to the fact that, beside the Romanian native population, other seven ethnic groups lived together: Austrians and Zipsers, Jews and a few families of Slovaks, Poles, Armenians and Ruthenians. 
The 'foreigners' had to deal with difficult life circumstances because of the climate and of the neighbourhood relationships. Despite the fact that the Austrian and Zipser settlers' home regions were similar as regards landforms and climatic indices to the ones in Maramures, in the Vaser Valley they coped with floods, long snowy and rainy periods, low fertility soil, the famine at the end of the $18^{\text {th }}$ century, the epidemics with multiple deaths, and that was why in many cases they decided to leave. Potato cultivation was introduced late. In 1789, the twelve registered potato plots were proof that acclimatation and production improved (SchmitZBerger 2003, p. 60; Ardelean 2011, p. 72; TOMi 2005, p. 99).

Other difficult periods that decimated the population of Vişeu de Sus/Oberwischau were the famine ones of 1816-1817 and the cholera and plague of 1831, 1838, 1840, 1870, 1873 and of 1893 (Tомi 2005, p. 106).

In Figure 1, we represented the evolution of the population number in Vişeu de Sus/ Oberwischau and the proportion of the diverse ethnic groups with a Romanian majority increasing gradually until 2002, when out-migration was high because of inhabitants' seasonal jobs in Italy, Spain, Ireland, Germany, etc., as well as because of the Zipsers' eventual departure to Germany. Thus, the number of inhabitants in this settlement began to decrease.

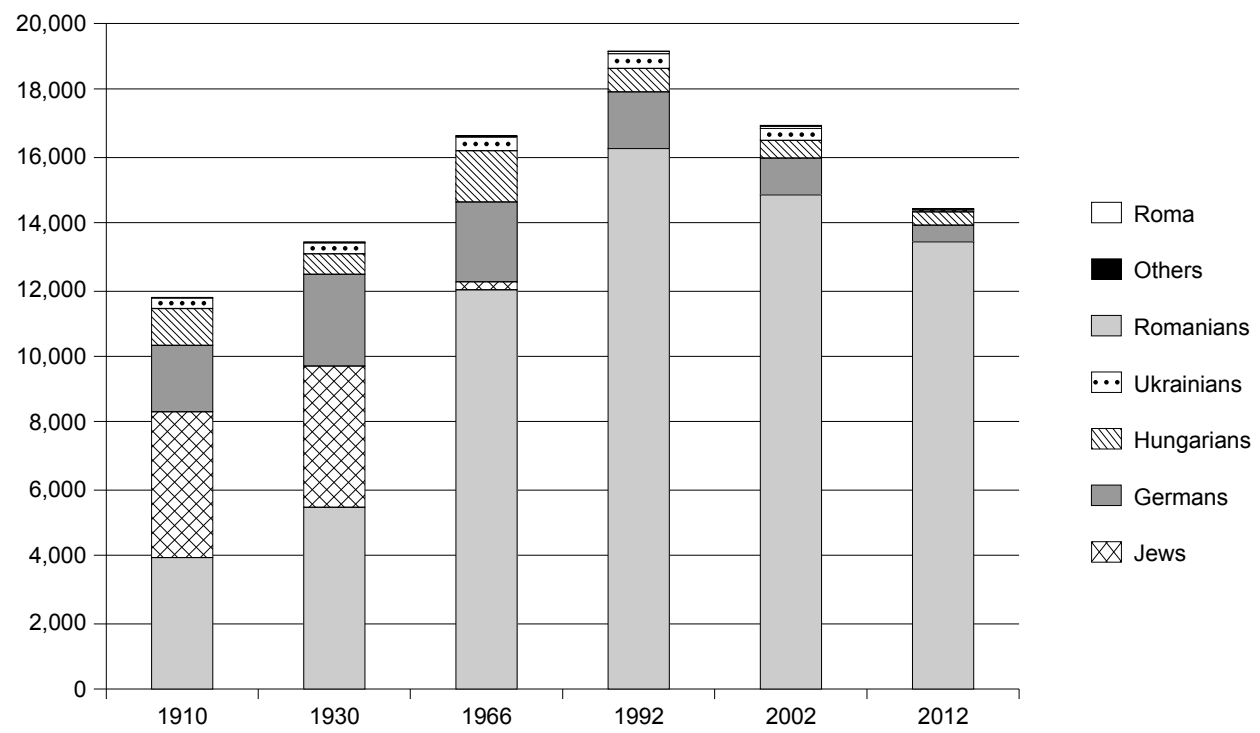

Quelle: Population censuses

Fig. 1: Evolution of the population structure in Vişeu de Sus/Oberwischau

Moreover, except Jews' deportation (1944/45), there were no significant gaps determining a change in the diverse ethnic groups' percentages. The Jews' negative trend was even more significant after deportation because initially there were approximately 7,000 Jews in Vişeu de Sus/Oberwischau and in its surroundings. The German and Ukrainian po- 
pulation have decreased constantly. On the other hand, the Hungarian and Roma population are the two ethnic components characterised by numerical permanence.

Vişeu de Sus/Oberwischau has been observing the negative trend in the population statistics of Romania, because it has registered $2 \%$ population decrease from one census to another, starting with 1992.

The majority and minority percentages in Vişeu de Sus/Oberwischau were always sensitive, especially before World War II and mainly because both Jews and Germans (either Austrians or Zipsers) had similar numbers. In addition, the most frequent position changes occured to the Germans and to the Jews. In 1910, in Vişeu de Sus/Oberwischau, they registered more Jews than Romanians and Germans. As numbers were very close, one cannot speak about majority and minority in Vişeu de Sus/Oberwischau, at least until after World War I. Nevertheless, if one takes into account also the unofficial, but more credible situation in which Jews declared they were Germans, especially before 1900, then other issues appear (SCRIDON 2012a).

The data we analysed were the official ones from censuses. But censuses did not offer clear situations either because certain oppressions or advantages determined the Zipsers to declare that they belonged to the Hungarian group for instance. Another trap of statistical data was the fact that there was no mentioning of the Zipsers' group (as a category for ethnic affiliation) in the census questionnaires. Some of the respondents declared that they were Germans or they were affiliated to other categories (SCRIDON 2012a).

If in the period between World War I and World War II the proportion of Zipser Germans in the settlement of Vişeu de Sus/Oberwischau was $50 \%$, about the time of our research, they represented $3.5 \%$ of the total population (Томг 2005).

Nevertheless, the Zipsers maintained a permanent habitation along the Vaser Valley and in the Tipserai Quarter and therefore their presence was obvious during all historical periods as they got more or less directly involved into the major social events of the community.

\subsection{The Zipsers and the Other}

Historically and sociologically, living together (in German: miteinander) or near the Other (in German: nebeneinander) produced significant changes in peoples' relationship to the Other. The self-image appears through continuous comparison to the Other, in most cases to Romanians, who perceived the Zipsers as foreigners. In a series of descriptive texts of the Zipsers' community in Vişeu de Sus/Oberwischau, from the $19^{\text {th }}$ century to the present, they appeared as the Other, foreigners, they are not ours:

"The 2,700 inhabitants and the 7,000 foreigners" or "houses with one or two floors, all of them with Jewish commercial plates, among which the majority are of a Polish family." (Iorga, Romanian historian, 1906, p. 306)

or

Question (Q) - "What do you think about the Zipsers?"

Answer (A) - "The Zipsers are industrious people, working hard to gather a little wealth from this poverty. [...] They were tall men and they were all good forestry workers. The Ukrainians who were tall men and much stronger had large palms 
and this made quite a difference when they worked with wood. Romanians rather liked to drink; they cut the wood in the forests and then brought it to the river. The women in Tipserai did everything in the household, and every second house had a cow and it was hard and women gathered leaves to feed these cows." (Joszef, Hungarian, 80 years old)

They call the Romanians in Vişeu de Sus/Oberwischau "they, the Romanians" and during difficult moments in a discussion, the Zipsers call them Vlachs. This word is deprecatory and it is used when reproaching and blaming. The positive valorisation of the German community, the negative one of the Romanians and the superficial one for the Hungarians were significant during the identity building process (SCRIDON 2012a).

The magyarisation process had a powerful impact on the Zipsers and not only on them, although the last more active phase was a short one (1939-1944). As they were compelled to learn and use Hungarian, to change their family names to Hungarian ones so that they had better living conditions or to be allowed to listen to the church service in German, some of the Zipsers gave in and observed the Hungarian system and requests. The example below shows that during the period when magyarisation was more active, offering advantages for the Hungarians in administration had the aim of creating the image of a better standard of living and thus it was a method of convincing the German ethnics and the other to leave behind their affiliation and choose the Hungarian one. The fact that some Hungarians were not Hungarians from the beginning, but they "turned themselves into Hungarians" has as proof the German family names translated into Hungarian (e.g., Groß/ Nagy) or the changing only of the first name (e.g., Zipsers gave their children Hungarian first names such as in the case of Wagner Poldi, Zeppelzauer Schandor in Vişeu de Sus/ Oberwischau).

Q - "Did the Zipsers have any difficulties in their relationships with the other?"

A - "They had indeed plenty! Here it was how it was, but the Hungarians were always different. The Hungarians were very smug and they turned themselves into Hungarians, and I don't know why [...] because they hadn't been Hungarians from the start. Hungarians had everything." (Maria S., Zipser, 74 years old)

The flux of changes had different intensities and directions that impacted on all cohabitant ethnic groups. The convergent directions were those related to the management of work, of their territory, to the religious and traditional meeting points within their culture, while the divergent ones, focusing on preservation, were at the linguistic and religious levels. For the Zipsers' group in Vişeu de Sus/Oberwischau, we could notice convergent axes also at the level of their idiom, especially because of the magyarisation period of the administrative and education systems and of the church institution. Thus, a significant number of words in the Zipsers' idiom within this settlement are from Hungarian.

A - "They, jâzii (the Jews) spoke Hungarian, a kiczi (little - in Hungarian). We called their street jido utco (the Jewish street - in Hungarian). Anna neni (in Hun- 
garian) and Joszi bacsi (in Hungarian), my aunt and uncle from my mother's family were in good relationship with their [Jewish] family." (anonymous, Zipser, 91 years old)

A - “[...] when I went to the market I would speak Romanian, when I met my sister, I would speak the Zipsers' idiom, and with my mother-in-law I would speak Hungarian because she was Hungarian.” (Korodi, Zipser, 95 years old)

Opening to the Other was possible by learning the neighbours' language. Linguists call the present Zipsers' idiom German idiom from Vișeu de Sus/Oberwischauer Mundart. Alienation from the first Zipser generations' idiom in Vişeu de Sus/Oberwischau, the influence of literary German, of Romanian and of Hungarian as well as the contextual synonymy process led to the creation of a new idiom. Words such as gogoschar/der Paprika, buletin/der Ausweiß, maschina/das Auto are common in the Zipsers' idiom.

Each ethnic group preserved as much as possible their tradition and customs related to costumes or clothing. People from each ethnic group had their specific place within the community and could be recognised through clothing, while certain features were visible from posture and appearance. The Zipsers did not preserve the costumes worn in their native region. Because of their low standard of living during the first years after settling, those traditional clothes were replaced with clothes depending on the style of the respective epoch or on available materials on the markets of the town.

Q - "How do you recognise a Zipser in a crowd of people or anyone else in order to assign him or her to an ethnic group?"

A - "I still remember that in the 1940's-1950's they were different from one another because of the clothes they wore. But during that time the Jews had curly sideburns (peyot) [Paisli - Peót ha-Rosh - in the Yiddish spoken in Hungary], polecat caps, long coats, those were the Orthodox Jews, very Orthodox. They were educated people, very civilised and neat: There was a doctor, a printing worker, a Mister Glück with commerce, but they left with the first transports. Romanians wore white woven clothes and breastplates." (Korodi, Zipser, 95 years old)

After World War II, the inter-ethnic relationships in Romania were characterised by dominating and controlling the voice of the minority who tried to get closer to Western Europe, to Germany and Austria in the case of the German ethnics, while the Jews', Ruthenians' and Hungarians' number was insignificant. The biggest perception changes upon the Other took place during periods with big social and political changes.

Q - "[...] did you receive your monthly allowance of food similarly to the other people standing in the queue?" (This question was about the situation of the monthly allowance of food in the ration book, about any inequality issues, during the Communist period, because of ethnicity, kinship or other reasons.)

A - "When we stood in a queue to buy food, because that was the way things were then, we stood in a queue for oil, sugar, then the Romanians used to attack us with words and used to send us to Hitler: Go to Hitler, why do you take our bread?! 
Those were hard times and people were hungry and upset and they did not leave us in peace." (Maria H., Zipser, 75 years old)

Friendship sums up faithfully the meeting points between cultures: "Friendship, as an evolved form of human solidarity, remains an acknowledgement that beyond circumstances, people of different ethnic origins consider collaboration normal and inherent to the human condition [...] and only political and military disruptions may impact these relationships for a shorter or longer period." (RADOSAV 1994, p. 7) It seems that this was the solution through which each ethnic group was stable, and assimilation and acculturation in Vişeu de Sus had slow manifestation stages.

Friendship and collaboration are very well exemplified in Figure 2, where one may notice from the start not only the persons' ethnic origin, but especially their status within the hunt group. It may be far-fetched to consider an organised hunt group as a faithful image of the community in Vişeu de Sus/Oberwischau. Nevertheless, this photo is relevant from the historical perspective upon multiculturalism and upon collaboration with diverse aims

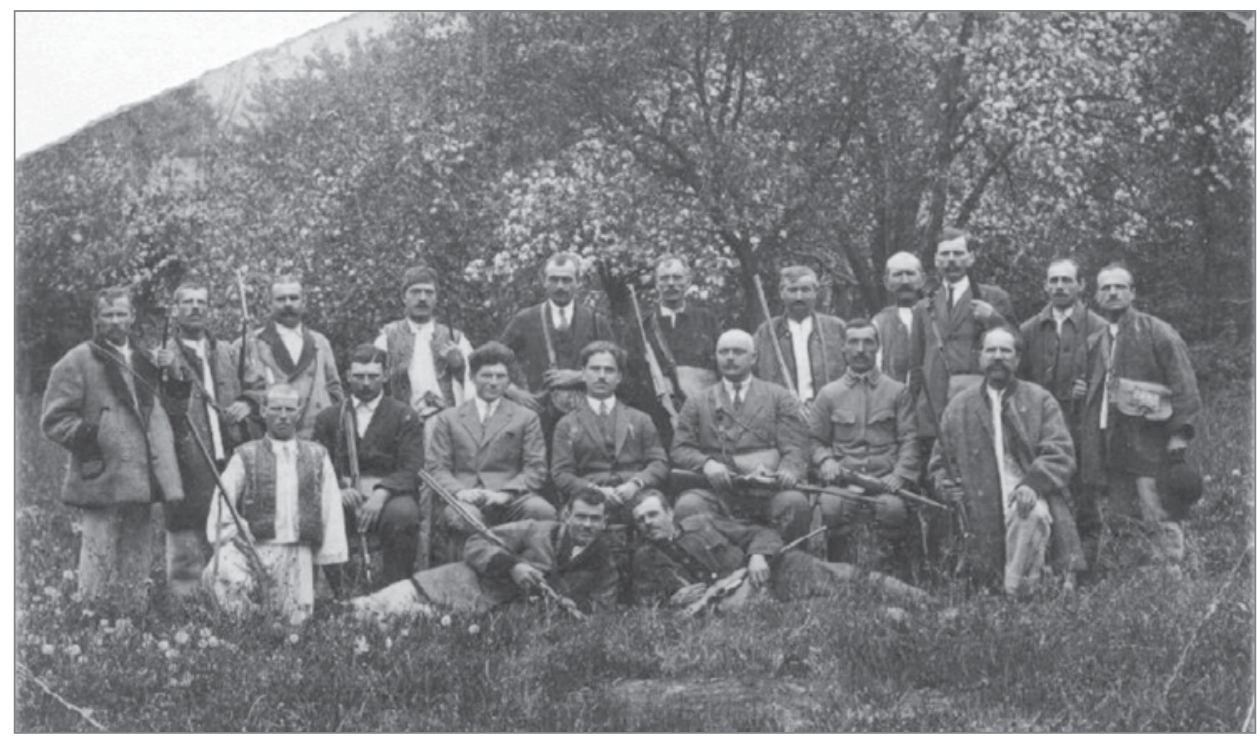

Source: JugOvschi W., private collection

Fig. 2: Hunt, Vişeu de Sus/Oberwischau, 1930

such as during the hunt and because of the hunters' status within a hunters' association. It is relevant that not everybody had the right to own a gun and to hunt. This photo was taken in 1930 on the occasion of a hunt organised in Vişeu de Sus/Oberwischau. It is easy to identify the Romanians, on the margins, wearing their traditional and usual clothes (white clothing, with breastplate or coat). Two Ukrainians may be identified due to their beards. The Germans and the Hungarians are in the centre of the photo, their clothing differentiating them from the Romanians and the Ruthenians. 
But most of the times the people remained indifferent, from the perspective of visible involvement, to the political problems and hardships that had an impact on the Germans and on the Jews. Similarly, the magyarisation period (1940-1944) had significant impact, along with the one of the Germans' deportation to Russia (1944/45).

Q - "Did you know any deported Jews that came back from labour camps?"

A - "There was a doctor, a Jew, very good doctor. This Jew had two children and a wife. And when there was this war, they took him to Auschwitz, and only he came back, his wife and two children didn't. They gathered them as if they were animals. Poor people, they suffered and lost so much. And we couldn't do anything; we just stood there and looked at what happened." (Maria S., Zipser, 74 years old)

Although there were close relationships, each ethnic group had its own very well defined social status and occupation. Recognising the Other's occupation, helping each other and doing certain jobs for the Other determined the ethnic groups to become close and supported opening to the others' activities and trusting their help. Most Zipsers were both well-known log drivers and skilful in wood processing activities, while some of them continued this tradition in building houses; the Romanians were agricultural workers; the Jews and the Armenians dealt in commerce, etc.

Q - "Were the Zipsers only forestry workers?"

A - "I knew that they were very good log drivers. There were also among them some, who built houses and roofs. Here it was like that: We knew that ours were good masons, from the Jews we would buy what we needed or they were doctors and shoemakers; the Romanians bred sheep and had horses for labour; and the Ruthenians worked with their hands. When we built our fountain, we called a Ruthenian to dig." (Maria H., Zipser, 75 years old)

The trend of the majority is to assimilate the minority. Either a long process or a fast, forced one, assimilation is eventually unavoidable and in direct dependence on the ethnic identity. In this context, the interdenominational relationships usually develop two directions. The first case is that of a conflict direction, under the threat of ethnical deterioration as in the case of the Transylvanian Landlers, or closing the community and restricting admissions, especially through rejecting mixed cultural marriages, as in the case of the Zipsers in Vişeu de Sus/Oberwischau (SCRIDON 2012a). These are the most common ways because of the majority's attitude based on stereotypes. In fact, cultural influences enrich each culture.

Opening up for receiving a foreigner in the family or in the community appeared when people found something they had in common. Religion was often the way to accept the Other, irrespective of his or her ethnicity. For the small group of the Zipsers, the Church was the permanent vertical and coordinating axis for preserving their ethnic identity in an Orthodox space. The Roman Catholic Church in Vişeu de Sus/Oberwischau started to accept mixed cultural marriages because of consanguinity and because of the singular diseases of the 1901-1910 period, and beginning with 1967 there was a larger opening through a 'reform', as the German speaking groups' territories were isolated in Eastern 
and Southeastern Europe, in the former Austrian territories (PAL 2006, p. 466). In the consciousness of the traditionalist common people in the last part of the $19^{\text {th }}$ century, the Church accepted interdenominational marriages. This also represents a step towards acculturation and assimilation.

$\mathrm{Q}$ - "Is your husband a Zipser?"

A - "A Zipser, yes, and Zipsers mostly married within their group. My mother told me not to talk to young men from another ethnic group because it was not a good thing to have foreigners in one's home. My aunt was against her son marrying her present daughter-in-law. And she agreed only after her daughter-in-law, who was a Romanian, had baptised in the Roman-Catholic religion." (Maria, Zipser, 72 years old)

\subsection{Zipsers' culture in Vişeu de Sus/Oberwischau}

In the situation of the ethnic groups, where their evolution and resistance was supplied by restrictive relationships with the Other, there is the case of communities living together and in our research these are the Zipsers, the Romanians, the Ruthenians, the Jews, the Hungarians and the Austrians (MifTODE et al. 2003). Their history proved that permissiveness or openness had increased very much to the present day, through culturally mixed marriages or through internal and external emigration. Nevertheless, the Zipsers are still a cohesive ethnic group (ILK 2011).

Moreover, the Zipsers' culture in Vişeu de Sus/Oberwischau had major impact in that area. Although nowadays cultural acts are public only during diverse holidays, some families observe them as they received them from their ancestors. Still, at present, their material and spiritual culture is fading away, not only because of the small number of Zipsers in Vişeu de Sus/Oberwischau or because of the high ageing rate, but especially as a result of lack of interest for their culture or because of historical misunderstandings. As the Zipsers from this settlement 'have spread' throughout Europe, they grouped themselves into three fora: one in Vişeu de Sus/Oberwischau (organised beside the German Democratic Forum in Vişeu de Sus/Oberwischau) and two in Germany (The Association of Vişeu de Sus/ Oberwischau Zipsers and The Association of Satu Mare Swabians and Vişeu de Sus/Oberwischau Zipsers).

Their material culture is represented by the material characteristics the Zipsers managed to bring forward anywhere they settled: the houses, the structure of the built space and of the inhabited one, the specific forestry constructions, the dams, the traditional food, etc. The Zipsers' spiritual part is mainly taken care of by old people that hand down their stories, tradition, customs, mentality, etc.

The characteristic holidays and tradition (e.g., Viflaimul - biblical theatre the Zipsers play on the occasion of Christmas; Fărşangul - masked ball organised before the religious fast periods during the year) represent the bond within their community and represent as many opportunities of handing them down to future generations. Both the old and the young participate and thus they maintain a permanence of organisation along the years and a participatory transfer of holidays' particularities. 
In our case study, ethnic diversity enabled unity and led to cultural perpetuation due to a mechanism of preserving ethnic identity with open access points, irrespective of individual will. At present, the number of representative ethnic groups is small as well as the ethnics' percentage within the community in Vişeu de Sus/Oberwischau: Germans $(4.03 \%)$, Hungarians $(2.57 \%)$, unknown ethnicity $(7.47 \%)$ and others $(0.95 \%)$ (INSTITUtUl Naţional de Statistică 2012). Therefore, preserving their ethnic identity depends on each individual's will and this is ensured rather by personal interest than by that of the community to preserve itself. Due to ethnic diversity and in contrast to cases where other ethnic groups or communities quickly assimilated (for instance, Anina in the mountainous part of Banat, and Iacobeni in Bucovina), the Zipsers in Vişeu de Sus/Oberwischau and the seven cohabitant ethnic groups, in different proportions and without major disparities especially until World War II, enabled the free manifestation of ethnic cultural identity, in interdependence with the other ones. It is important to understand the circumstances under which these ethnic groups entered this major social game (SCRIDON 2012a).

This multi-ethnic space is "an ideal study field for researching how identity borders are rebuilt and remodelled today [...]" (B̆̆LU 2003, p. 194). Even if being a Romanian represents the nationality, German is the ethnic affiliation, and the most frequent language is Hungarian. As a matter of fact, their degree of acculturation and assimilation is quite advanced so that the Zipsers in Vişeu de Sus/Oberwischau, from a linguistic point of view, have a Vişovean (from Vişeu) German dialect, as well as a different ethnic and cultural identity from the first colonisers in the $18^{\text {th }}$ century (ILK 2011). The young speak literary German, Romanian and a little Hungarian, and the old speak the Zipsers' idiom, Hungarian, Romanian and not so much literary German, the only exceptions being represented by the persons that graduated German schools (where teaching was in German). Their religion is Roman-Catholic, having a strong role for group cohesion and for maintaining their material and spiritual culture over centuries. The Roman-Catholic Church had a significant role after 1868, when Hungarians tried to assimilate also the German-speaking population in Vişeu de Sus/Oberwischau, these inhabitants choosing to adopt Hungarian language in order to be able to hold to their Roman-Catholic religion.

Vişeu de Sus/Oberwischau and the Vaser Valley form a mental space for the Zipsers' ethnic group. It is not only a part of space, but also a place, an emotional support reminding people of "sights, persons, events, smells, sounds they associate with this place" (TUAN 1974, 1977 apud JoRDAN 2014, p. 22).

\section{Conclusions}

The Zipsers' ethnic group had lived together with other ethnic groups for over two centuries. The specific forms of representing their ethnic identity space and interethnic relationships are under continuous transformation, present trends showing assimilation and cultural levelling. The specificity of this ethnic group and especially of its perpetuation was exactly the multicultural substratum that enabled respecting the Other, communication and help-based ethnic relationships, that is "living together (in German: miteinander leben)". 
Nowadays, the Zipsers' ethnic group in Vişeu de Sus/Oberwischau follows a negative trend both as a result of a strong ageing process and because of a decrease in the ethnics' number. Similarly to their idiom, which linguists called Oberwischauer Mundart, their culture undergoes a process of continuous changes and assimilation. The Zipsers have become somebody else when comparing them to their ancestors and, at the same time, they remained different when comparing them to the Romanians and to the other ethnic groups in Vişeu de Sus/Oberwischau.

One may best identify the features of inter-ethnic relationships during periods of local community crisis. The most significant moments were the deportation of Jews, the deportation of Germans to the Union of Soviet Socialist Republics (USSR) as well as local events that showed and changed people's perception upon the Other. Those showed that Miteinander and Nebeneinander underwent essential changes and went out of the usual path. Under such circumstances, totally different interests became dominant and the former Mit-/Nebeneinander partially overlapped. Cultural (including religious) identity and the entire spiritual plan were invaded by new group consensus elements, by other larger collective solidarities, new solidarity and also delimitation elements appeared. The voluntary, intrinsic elements remained in the background and the new, partially imposed and directed ones got in the foreground, at least temporarily.

In conclusion, the geography of the people in Vişeu de Sus/Oberwischau became a marker of local social relations. The construction of Zipsers' ethnic identity was done depending on the Other as a result of social transformation and of fragmenting triggered by political events.

\section{References}

Ardelean L. (2011), Franciscus Reti, „Historia Rei Cameralis” şi colonizarea populaţiei germane în Vişeu de Sus [Franciscus Reti, "Historia Rei Cameralis" and the colonisation of German population in Vişeu de Sus]. In: Ămbele Vişae, pp. 62-80. Vişeu de Sus, Eurotip.

BĂLU D. (2003), Multiculturalitate și identitate etnică în bazinul Tisei Superioare [Multiculturalism and ethnic identity in the Upper Tisza Basin]. Satu Mare, Editura Muzeului Sătmărean.

BäTZING W. (2011), „Neue Kulturgeographie“ und Regionale Geographie. Können die Ansätze der „Neuen Kulturgeographie“ auf die Regionale Geographie übertragen werden? Eine kritische Bewertung vor dem Hintergrund von 30 Jahren Alpenforschung ["New cultural geography" and regional geography. Is it possible to apply the approach of „New cultural geography” to regional geography? A critical assessment based on 30 years of Alpine research]. In: Mitteilungen der Österreichischen Geographischen Gesellschaft, 153, pp. 101-128.

Berner H. (2006), Aus dem Brotland ins Notland. Oberwischau. Siedlungs- und Kirchengeschichte, Erinnerungen, Sitten und Bräuche in Mundart [From the land spending bread to the land of hardship. Settlement and church history, memories, habits and customs in dialect]. Ravensburg - Satu Mare, Bion.

Bryden I. (2004), 'There Is No Outer without Inner Space': Constructing the Haveli as Home. In: Cultural Geographies, 11, 1.pp. 26-41.

Crouch D. (2010), Flirting with Space: Thinking Landscape Relationally. In: Cultural Geographies, 17, 1, pp. 5-18. 
DĂNCuŞ I., DĂNCuş M. (1999), Interferenţe culturale în centrul geografic al Europei [Cultural interferences in the geographical centre of Europe]. In: GEHL V.C.H. (ed.), Relaţii interetnice în zona de contact româno-maghiaro-ucraineană din secolul al XVIII-lea până în prezent, pp. 493-520. Satu Mare - Tübingen, Editura Muzeului Sătmărean.

Ferréol G. (2005), Cultură [Culture]. In: Ferréol G., JucQuoIs G. (eds.), Dicţionarul alterităţii şi al relaţiilor interculturale, pp. 181-184. Iaşi, Editura Polirom.

Ferréol G., JucquoIs G. (2005), Identităţi culturale [Cultural identities]. In: Ferréol G., Jucquois G. (eds.), Dicţionarul alterităţii şi al relaţiilor interculturale, pp. 328-339. Iaşi, Editura Polirom.

Gebhardt H., Reuber P., Wolkersdorfer G. (2004), Kulturgeographie - Leitlinien und Perspektiven [Cultural geography - guidelines and perspectives]. - http://www2.geog.uni-heidelberg. delanthropo/mitarbeiter/gebhardt/pdf/kulturgeographie.pdf (Accessed on 2 May 2015).

Hall St. (1995), New Cultures for Old. In: Massey D., JESS P. (eds.), A Place in the World? Places, Cultures and Globalization, pp. 175-213. Oxford, Oxford University Press, Open University Press.

Historia DOMUs, in the archive of the Roman-Catholic Church in Vișeu de Sus/Oberwischau.

ILK A.-J. (2011), Die mythische Erzählwelt des Wassertales [The mythical world of narratives of the Vaser Valley]. Linz, Adalbert-Stifter-Institut des Landes Oberösterreich.

ILovan O.-R. (2009), Ţara Năsăudului. Studiu de Geografie Regională [The Land of Năsăud. Study of regional geography]. Cluj-Napoca, Presa Universitară Clujeană.

Institutul Naţional DE Statistică (ed.) (2012), Recensământul populaţiei din 2011 [Population census 2011]. Bucureşti.

IoRga N. (2009), Neamul românesc în Ardeal şi Ţara ungurească la 1906 [The Romanians in Transylvania and Hungary in 1906]. Bucureşti, Saeculum I. O.

Jordan P. (2014), The Meaning of Bilingual Naming in Public Space for the Cultural Identity of Linguistic Minorities. In: Review of Historical Geography and Toponomastics, 9, 17-18, pp. 21-24. - http://www.geografie.uvt.ro/old/en/research/publications/rhgt/articles/rhgt_vol\% 2009_no\%2017-18/07_ART_JORDAN.pdf(Accessed on 2 May 2015).

JugovschI W., personal photography collection, Baia Mare. Photograph taken in 2012, with the owner's consent for publishing.

Mehedinți M. (2013), Identifying the Other: Transylvanian Ethnicities in the First Half of the $19^{\text {th }}$ Century as Viewed by Foreign Travellers. In: Transylvanian Review, 22, Supplement 3, pp. 249-259.

Miftode V., Nacu D., Cojocaru S., Sandu A. (2003), Dezvoltarea comunităţilor etno-culturale. Integrarea europeană și interculturalitate [Development of ethno-cultural communities. European integration and interculturality]. Iași, Expert Project.

Mills A. (2006), Boundaries of the Nation in the Space of the Urban: Landscape and Social Memory in Istanbul. In: Cultural Geographies, 13, 3, pp. 367-394.

Mitu S. (2013), Local Identities from Transylvania in the Modern Epoch. In: Transylvanian Review, 22, Supplement 3, pp. 237-248.

PAL M. (2006), Căsătoriile mixte în legislaţia Bisericii Catolice: aspecte istorico-juridice [Mixed marriages in the Roman Catholic Church legislation: Historical and legal issues]. In: Studia Theologica, IV, 4, pp. 465-483.

Radosav D. (1994), Donbas, o istorie deportată [Donbas, a deported history]. Ravensburg, Landsmannschaft der Sathmarer Schwaben in der Bundesrepublik Deutschland.

RAZA A. (2013), Is Culture a Large Prison for Individuals? - https://www.researchgate.net/post/ Is_culture_a_large_prison_for_individuals (Accessed on 12 March 2013).

Riceeur P. (1990), Histoire et vérité [History and truth]. Paris, Esprit. 
ROCHER G. (1970), Introduction à la sociologie générale, vol. 1: L'Action sociale [Introduction into general sociology, vol. 1: social action]. Paris, Seuil.

Rose M. (2010), Pilgrims: an Ethnography of Sacredness. In: Cultural Geographies, 17, 4, pp. 507 524.

Schmitzberger G. (2003), Beiträge zur Organisation der Waldwirtschaft in Oberwischau (Marmarosch) im letzten Viertel des 18. Jahrhunderts [Contributions to the organisation of forestry in Oberwischau (Maramureş) in the last quarter of the $18^{\text {th }}$ century]. GeHL V.C.H. (ed.), Relații interetnice în zona de contact româno-maghiaro-ucraineană din secolul al XVIII-lea până în present, pp. 47-64. Satu Mare - Tübingen, Editura Muzeului Sătmărean.

Schmitzberger G. (2014), Die Entstehung des Waldwesens im Wassertal [The evolution of forestry in the Vaser Valley]. Nürnberg, Haus der Heimat.

SchneEberger M., LANGe F.M. (1998), Die rumänischen Waldkarpaten, Maramureş, Vişeu de Sus und ein Abstecher in die Bukowina [The Romanian Wooden Carpathians, Maramureş, Vişeu de Sus and a trip to Bucovina]. Berlin, Schelzky \& Jeep.

SCRIDON I. (2012a), Grupul etnic al țipserilor din România. Studiu diacronic al schimbărilor de reprezentare a spațiului identitar etnic în Vișeu de Sus, Maramureș [The ethnic group of Romanian Zipsers. Historical study on representation changes of the identity space in Vişeu de Sus, Maramureş]. PhD Thesis, Babeş-Bolyai University Cluj-Napoca, Faculty of Geography.

SCRIDON I. (2012b), Neighbourhood Relationships between German Ethnic Groups from Romania. Case Study: the Zipsers from Vişeu de Sus, Maramureş County. In: Journal of Settlements and Spatial Planning, 3, 1. Cluj-Napoca, Presa Universitară Clujeană, pp. 51-56.

SCRIDON I. (2012c), Abstract of the PhD Thesis: Grupul etnic al țipserilor din România. Studiu diacronic al schimbărilor de reprezentare a spațiului identitar etnic în Vişeu de Sus, Maramureș [The ethnic group of Romanian Zipsers. Historical study on representation changes of the identity space in Vişeu de Sus, Maramureş], available at http://doctorat.ubbcluj.ro/ro/ sustinerile-publice-ale-tezelor-de-doctorat $/ ?$ an $=2012 \&$ facultate $=5 \&$ domeniu $=25 \&$ pagi$n a=2$ (Accessed on 9 September 2015).

Sletto B. (2002), Producing Space(s), Representing Landscapes: Maps and Resource Conflicts in Trinidad. In: Cultural Geographies, 9, 4, pp. 389-420.

Smith M.F. (2012), Working in Different Cultures. In: Clifford N., French S., Valentine G. (eds.), Key Methods in Geography, $2^{\text {nd }}$ edition, pp. 157-172. London, Sage.

Soporan F.D. (2014), Mission and Identity: Foreign Queens, Founding Dynasties and Their Subjects in Central and Eastern Europe. In: Transylvanian Review, 23, 3, pp. 108-119.

Tomi M.N. (2005), Maramureşul istoric în date [Historical Maramureş in dates]. Cluj-Napoca, Grinta. 